\title{
LA FILIACIÓN MATERNA Y PATERNA EN EL DERECHO ISLÁMICO. DERECHO SUSTANTIVO Y REFORMAS EN LOS SISTEMAS JURÍDICOS ACTUALES
}

Ma MAGDALENA MARTÍNEZ ALMIRA

Universidad de Alicante

\section{CONSIDERACIONES GENERALES}

La presencia en España de un importante número de personas que profesan la religión islámica ha favorecido el interés por el Derecho islámico en sus diversas manifestaciones. En este sentido, son muchos los expertos en Derecho que han planteado cuestiones relativas a instituciones del ámbito privado respecto a matrimonios mixtos, como la familia, la filiación o la adopción respecto, y también por razón de las demandas presentadas ante tribunales españoles por matrimonios contraídos validamente entre musulmanes en sus países de origen $^{1}$.

Ahora bien, el asentamiento de los musulmanes en España, bien de forma temporal o bien definitiva, obliga al jurista interesado en este sistema jurídico a considerar la pluralidad de textos normativos propios de cada nacional. Se trata de un Derecho que ha experimentado un proceso de modernización en los últimos ciento cincuenta años, especialmente respecto al Derecho de familia, una materia que al menos conceptualmente presenta ciertas características en modo alguno comparables al derecho occidental ${ }^{2}$. En efecto, en el Derecho islámico

1. Remítase el lector a BORRAS, A., y MERNISSI, S.: El islam jurídico y Europa, Barcelona, Icaria, 1998. Y sobre la incorporación de estos sistemas jurídicos al mismo ámbito CASTRO, F. y ALLIEVI, S.: Islam and European Legal Sistems, Milan-Leicester, Oxford University Press, 2001, pp. 154 y ss.

2. Aluff BeCK-PeCCOZ, R.: La modernizazione del Diritto di Familia nei Paesi arabe, Milano, Giuffré, 1990, pp. 160-177. Pese a no contener muchas de las recientes reformas acontecidas en los países africanos, el lector interesado en estas cuestiones no puede dejar de remitirse a la obra de conjunto PRADER, J.: Il matrimonio nel mondo: celebracione-nullitá e scioglimiento del vincolo, $2^{\mathrm{a}} \mathrm{ed}$. aggiornata, Padova, CEDAM, 1986; el texto aproxima a una situación global respecto a la institución matrimonial en los países de tradición islámica y a los cambios acaecidos en los últimos cuarenta años respecto a los textos surgidos fruto de la codificación. 
el contrato de matrimonio (nika $\left.h^{3}\right)$-tanto lícito como ilícito, si se toma en consideración que la mut'a es una institución legal para los šiies duodecimanos ${ }^{4}$-, el repudio, la filiación y los efectos legales y patrimoniales derivados de estas instituciones jurídicas son instituciones que guardan su singularidad desde el punto de la sistemática del derecho, tartīb, y en modo alguno forman parte de un materia unitaria como así sucede en otros sistemas jurídicos.

Una de las instituciones que mayor interés suscita por las sucesivas cuestiones que se plantean ante los tribunales es la filiación y el reconocimiento de la paternidad, sobre todo en relación a los procesos de repudio y divorcio que se sustancian en nuestro territorio. Los problemas que surgen cuando las autoridades españolas deben identificar la autoridad competente en un Estado extranjero para conocer estas demandas son complejos, especialmente en lo que a los países islámicos se refiere, tanto del ámbito del Magreb como del Masriq, e incluso en áreas aún más alejadas. Nótese que son muchos los residentes en España procedentes de Nigeria, Níger, Malí, Sudán, Senegal, Somalia, Argelia, Túnez y Marruecos y, en menor cuantía, de Irán e Iraq; países cuya legislación en la materia que nos ocupa difícilmente es conocida en nuestro país ${ }^{5}$. La fluidez con la que se produce el intercambio de información sobre la legislación vigente en aquellos países depende en gran medida de las relaciones diplomáticas y de la expresa reglamentación sobre traspaso de información y competencias en estas materias 6 .

3. S.v. «nikāh», en Encycoplaedia of Islam (en adelante $E I^{2}$ ), vol. VIII, Leiden, Brill, 1995, pp. 26-35.

4. Un matrimonio cuya validez depende de la constatación de dos condiciones. La fijación del término de cohabitación, pudiendo ser un día, un mes, un año o un número determinado de años; y en segundo lugar la fijación de la dote. En este caso el divorcio no es factible y el contrato expira con el término del plazo establecido en el mismo. S.v. "muta'a», en $E I^{2}$, vol. VII, Leiden-Nueva York, Brill, 1993, pp. 757-759.

5. Aunque sería interesante abordar el derecho sustantivo de cada uno de estos países en relación a la filiación y las formas de reconocimiento de la paternidad, así como sus efectos, este planteamiento excede en cuanto a posibilidades materiales el objeto de este trabajo;así pues se ha optado por hacer un seguimiento de aquellos textos jurídicos de países del Magreb (Túnez, Argelia y Marruecos) y del Masriq -especialmente de Egipto y Sudán- sin olvidar aquellos otros de la zona más oriental en los que, si bien la mayoría de la población es musulmana oficialmente, no se aplica la šarì'a, y entre estos cabe citar Jordania, Siria, Iraq o Kuwait, sujetos a la influencia británica. Kuwait, por ejemplo, adoptó tras la independencia un modelo jurídico basado en las propuestas de al-Sanhuri y concluyó con la elaboración de un Estatuto Personal en 1984. Abd al-Razzaq Ahmad al-Sanhuri (1895-1971) fue discípulo de Lambert, y desarrollo un modelo normativo de amplia difusión en el mundo árabe, tanto en el Magreb, en Libia, Argelia y los países del desmembrado Imperio otomano, como Siria (1949), Iraq (1951) y Jordania (1976), conocido bajo el nombre de "modelo egipcio». El proyecto de código civil egipcio fué adoptado en Libano, Túnez, Argelia y Marruecos, habiéndose redactado otro para Siria, Transjordania, Iraq y Palestina. Véase CASTRO, F.: «La Codificazione del diritto privato negli stati arabi contemporanei», Rivista de Diritto Civile, 4 (1985), I, pp. 384-447. CIlARDO, A.: Il Diritto islamico e il sistema giuridico italiano: le bozze di intesa tra la Repubblica Italiana e le associazioni islamiche italiane, Nápoles, Edizioni Scientifiche Italiane, 2002, p. 267.

6. De hecho el punto de partida ante esta problematica es la determinación de la competencia por parte del Estado en el que se desarrolla el procedimiento en cuestión. Dos son los preceptos operativos: en primer lugar el art. 10 del Convenio de la Haya de 1996 respecto a la competencia del 
Los continuos flujos migratorios de personas procedentes de países en los que rige el Derecho islámico han dado lugar a que en los tribunales españoles se planteen situaciones que obligan a considerar y analizar la normativa de los países de origen, especialmente en relación a las cuestiones sustantivas surgidas sobre la filiación. Sin lugar a dudas la filiación es en el Derecho islámico una institución que presenta algunas divergencias respecto a otros sistemas jurídicos. La filiación define el derecho al parentesco correspondiente tanto al padre como al hijo. Un derecho que el ordenamiento musulmán reconoce al padre desde el momento en que el feto se encuentra en el útero materno. En este sentido, el primer derecho que adquiere el nasciturus es el mantenimiento por parte del padre y los cuidados necesarios respecto a la madre durante el periodo de su embarazo y hasta el alumbramiento. Desde ese momento, y hasta la mayoría de edad, el niño atraviesa por una serie de etapas vitales en las que se reconocen derechos concretos garantes de su crecimiento y desarrollo en condiciones determinadas ${ }^{7}$. Los derechos de reconocimiento paterno, custodia, mantenimiento y guarda del hijo están estrechamente relacionados con la institución del matrimonio, y por tanto estos dependen, en última instancia, de la legítima unión entre los cónyuges por razón del contrato que entre ellos hayan celebrado, y que en aquellos países de tradición malikí el criterio seguido es la guarda ejercida por los agnados ${ }^{8}$.

Es importante hacer una referencia a la diversidad de situaciones que se derivan de la normativa contenida sobre estas instituciones en los Códigos y Estatutos personales que rigen en los distintos países de tradición islámica. Hay que tener en cuenta también que la filiación en el Derecho islámico responde a un esquema propio y singular, circunstancia que permite una mejor compren-

juez español para conocer demandas de nulidad, separación o divorcio y responsabilidad parental ante demandas presentadas de mutuo acuerdo siemrpe que alguno de los cónyuges resida en España; en segundo lugar los arts. 8 y 9 del citado Convenio en los que se establece que respecto a los derechos del menor fruto de un matrimonio serán las autoridades del Estado en las que el menor tiene su residencia, las que cedan su competencia a las autoridades de otro Estado en el que se esté conociendo una demanda de nulidad, separación o divorcio de los padres del niño. Así pues, los procesos iniciados en España obligarán a los tribunales españoles a solicitar permiso para adoptar las medidas necesarias para la protección del menor y el respeto de sus derechos, ante los supuestos de divorcio o separación de los padres. Sobre las dificultades que día a dia se producen y las vías de solución véase ARENAS GARCÍA, R.: Crisis matrimoniales internacionales. Nulidad matrimonial, separación y divorcio en el nuevo derecho internacional, Santiago de Compostela, Universidad de Santiago, 2004, pp. 78-83. Y en relación a las distintas problemáticas surgidas por inadaptación e inadecuación de los textos normativos al Derecho español MotilLA, A. y LORENZO, P.: Derecho de familia islamico. Los problemas de adaptacion al derecho español, Madrid, Colex, 2002, $1^{\circ}$ ed. Remítase el lector al artículo de MENHOFER, B.: «Enfant et patrimoine dans la recontre des civilisations", en J. Carlier J. y Verwilghen (eds.): L'estatut personnel des musulmans: droit comparé et droit international privé, Bruxelles, Verwilghen, 1992, pp. 356-377.

7. NASIR, J.J.: The Islamic Law of Personal Status, London, Graham and Trotman, 1986, pp. 156-169.

8. NASIR, J.A.: The islamic law of personnal Statuts, $2^{\circ}$ ed., London-Dordrecht-Boston, Graham and Trotman, 1990, p. 50. En este sentido el orden seguido es el de descendientes, ascendientes, los hermanos y los hijos de éstos, y finalmente los tios agnados y sus hijos. 
sión del contenido de las demandas formuladas por los musulmanes residentes en territorio español, sobre todo a la luz del Derecho comparado?.

\section{EL MARCO JURÍDICO DE LAS RELACIONES FILIALES}

\subsection{Presunción de paternidad}

La relación filial de parentesco, nasab ${ }^{10}$, se establece en el Derecho islámico mediando matrimonio válido; la presunción de paternidad que tiene en las palabras de Mahoma su justificación última: «el hijo pertenece al lecho», al-walad lil-firas $\mathfrak{s}^{11}$. Ello no obsta para que la doctrina haya reconocido otras posibilidades con base en el citado ordenamiento jurídico, aún con desigual aceptación entre las distintas escuelas jurídicas, y así sucede con el reconocimiento de la paternidad $\left(i q r \bar{a} r^{12}\right)$ y la evidencia.

El parentesco es definido como un derecho del hijo y del padre. En efecto, la relación de parentesco confiere una serie de derechos y obligaciones entre ambas partes, pero de forma especial del progenitor masculino respecto al recién nacido; entre los derechos destacan el derecho a la herencia, a la guarda y a la custodia hada ${ }^{13} a^{13}$, del hijo durante su minoría de edad. Estos derechos son reconocidos al padre biológico y la madre respecto al hijo, por lo que el parentesco y la relación filial son instituciones de derecho que confieren al hijo el estatuto de legitimidad ${ }^{14}$.

La filiación (nasab) se inicia, pues, desde el momento en que el varón tiene conocimiento del embarazo de la mujer fruto de la relación conyugal, presumiendo la doctrina que la concepción se deriva de las relaciones conyugales dentro del matrimonio legítimo. El hombre asumirá desde ese momento los cuidados y el mantenimiento de la esposa, hasta el nacimiento del concebido. Una obligación que en el momento del alumbramiento abre otra serie de expectativas respecto al niño, y que tiene en el acto de la imposición del nombre

9. Calvé Corbalán, C.: "Filiación», cap. IV, Tratado de derecho de familia. Aspectos sustantivos y procesales adaptados a las leyes 13/2005 y 15/2005 (P. González Poveda, ed.), Pozuelo de Alarcón, Sepín ediciones, 2005.

10. s.v. «nasab» en $E I^{2}$, vol. VII, Leiden-Nueva York, Brill, 1993, pp. 967-968 y MAíllo SALGADO, F.: Diccionario de derecho islámico, Gijón, Trea, 2005, pp. 274-275.

11. Al-BuHĀễ: Les traditions islamiques, trad. Houdas et Martel, París, Maissoneuve, Vol. III, p. 100. La expresión ha sido justificada en la actualidad en alusión a la mujer con la que es lícito mantener relaciones sexuales, en virtud del contrato que legitima la relación conyugal. Sobre estas cuestiones Alluffi-BeCK-PeCCOZ, R.: La modernizzazione del diritto islamico..., op. cit., pp. 155-159.

12. Las condiciones de validez se refieren tanto al declarante (al-muqir) que debe ser púber y sano de mente, no pudiendo manifestar su declaración mediante fuerza o presión alguna; al beneficiario (al-muqar lahu), que debe existir o al menos haber sido ya concebido; y al objeto de reconocimiento (al-muqar bihi) y respecto a éste se ha de pronuniciar en un acto unilateral y debe existir, sin duda; s.v. «iqrār» en EI', vol.III, Leiden-London, Brill, 1986, pp. 1078-1080.

13. S.v. «hadāna» en $E I^{2}$, vol. III, Leiden, Brill, pp. 16-19.

14. Y así es revelado en el Corán, XXXIII, 4-5; las alusiones del texto coránico a este tema se refieren a la edición de Julio Cortés, Barcelona, Herder, 1986. La materia es objeto de estudio por NASIR, J.J.: The Islamic law..., op. cit., pp. 170-189. 
el momento más trascendental a nivel de reconocimiento público en el seno de la Comunidad islámica.

El hecho de que los hijos nacidos fuera de la relación matrimonial no sean reconocidos legítimos, y se les considere fruto de la fornicación, ha motivado que el embarazo sea la situación de hecho que mayores controversias suscite entre los juristas islámicos, al menos en cuanto a la determinación del periodo mínimo de gestación, considerado desde aquel en que tuvo lugar la celebración del contrato matrimonial. Ello se debe a que, si bien en la actualidad se ha determinado el período mínimo de gestación en seis meses, la tradición prolongaba el término máximo del embarazo entre dos y cuatro años, según las distintas escuelas jurídicas ${ }^{15}$. El plazo comienza a computarse desde el momento en que es factible la relación conyugal entre los esposos ${ }^{16}$, situación que favorece la presunción de paternidad a favor del marido. Este hecho recibe distinto tratamiento por parte de las escuelas; en concreto, en la escuela hanafi $i^{17}$ rige el criterio de que desde el momento mismo de la conclusión del contrato se presume la paternidad al marido siempre que éste sea considerado apto para la consumación, incluso si niega haber mantenido relación sexual alguna. De este modo, siempre cabe el reconocimiento de la paternidad cuando la relación entre los cónyuges sea, al menos, teóricamente posible; de forma que si no tiene lugar la consumación del matrimonio por causa del marido, éste estará obligado hacia la mujer por incumplimiento del acuerdo nupcial ${ }^{18}$.

En la actualidad los Códigos y Estatutos personales regulan y normalizan esta materia, y justifican las bases legales establecidas para poder acreditar y justificar de forma automática el nasab o relación filial paterna; para ello se considera el plazo comprendido desde el término mínimo de la gestación (seis meses) hasta el máximo (un año) como término viable en el que puedan haber tenido lugar relaciones sexuales ilegítimas que afecten al fruto de aquéllas. En estos casos el hijo nacido fuera del matrimonio tendrá la consideración en el

15. Los hanafies prolongaban este término hasta un máximo de dos años, los šaf'ies y hanbalies hasta cuatro años; y los malikíes hasta incluso siete años. Este tema es objeto de estudio y análisis conforme a la tradición por SANTILLANA, D.: Istituzioni di diritto musulmana, con riguardo al sistema malichita e sciafiita, Roma, Istituto per l'Oriente, 1929-1938, 2 vols; vol. I, p. 237.

16. En materia de matrimonio, la capacidad de las partes es uno de los requisitos para la válida celebración del contrato; así pues la intervención del walì se justificaba antaño por la incapacidad temporal de la hija; la patria potestad ejercida por el padre de la hija virgen, legitimaba su actuación pudiendo casar a la hija incluso antes de la pubertad. Los requisitos del contrato matrimonial son enunciados por la doctrina malekí a través de ${ }^{3}$ ALĪL IBN Iș̣̂̄Q: Il Muhtașar: Sommario del Diritto Malechita, 2 vols, Milan, 1919, trad. Por I. Guido-D. Santillana, Roma, Ulrico Hoepli, t. II, pp. 5 y 41.

17. SCHLEIFER, A.: "The Legal Aspects of Marriage According to hanafi Fiqh», Islam Quaterly, 29 (1985), pp. 193-219.

18. La escuela malekí se ha ocupado especialmente de los efectos derivados de la no consumación así como del desistimiento unilateral posterior al concierto entre las partes sobre la forma y modo en que se celebrará el matrimonio de la impúber; en estos casos en los que no hay consumación, el marido estará obligado a pagar la mitad de la dote en caso de repudio. IBN 'ĀṣıM: Op. cit., v. 356, p. 187. 
Derecho islámico de hijo fruto de la fornicación, situación que comporta serios efectos negativos en atención a sus derechos ${ }^{19}$.

Muchos países islámicos adaptaron en la primera mitad del siglo XX la legislación en materia de presunción de paternidad con el fin de legitimar la relación filial entre el niño, nacido antes del transcurso del plazo mínimo legal del embarazo, y el padre, siempre y cuando el parto tuviera lugar dentro del matrimonio. En este sentido, las reformas acometidas en Túnez han sido punto de referencia para otros países del mismo entorno, pero especialmente de aquellos seguidores de la escuela malikí; en efecto, la citada escuela estima que el hijo concebido antes de la celebración del contrato matrimonial, y por tanto previo al matrimonio válido es atribuido, mediante presunción automática, al marido. Y así es recogido por la legislación del marco magrebí ${ }^{20}$.

\subsection{El reconocimiento de la paternidad (iqrār)}

Es un acto jurídico voluntario y que supone la declaración por parte del padre natural de esa situación de hecho, es decir de la atribución de su paternidad. El reconocimiento por parte del padre tiene su momento más significativo tras el alumbramiento y la aceptación de las congratulaciones de sus convecinos. De manera que siguiendo estos presupuestos el hijo nacido fuera de la relación conyugal, y por tanto concebido por razón de la fornicación, no puede ser vinculado, en principio, al padre por presunción ni por reconocimiento expreso en el que se haga mención a esta irregularidad.

El acto jurídico por el que se reconoce la paternidad adquiere la consideración de confesión o declaración que afecta a derechos de terceros y expresamente del hijo. Es un instituto cuya validez depende de la concurrencia de una serie de elementos, definidos por los juristas $(f u q a h \bar{a})$, que confieren validez al acto. Las fórmulas de reconocimiento han de ser inequívocas, no pudiendo aludir al carácter ilícito de la relación entre el hombre y la mujer; se exige también una diferencia de edad mínima entre el padre y el hijo; conforme a la escuela

19. La duración máxima del embarazo se toma en consideración en base al cálculo de los períodos del ciclo menstrual, o bien desde el momento del alumbramiento, o bien desde el momento del fallecimiento del marido otrora de la ruptura de relaciones con motivo del repudio definitivo (talāq al-bā’in); sobre esta modalidad, véase voz «talaq» en $E I^{2}$, vol. X, Leiden, Brill, 2000, pp. 151-157. Y en cuanto al reconocimiento en los ordenamientos jurídicos actuales de los países islámicos: ALLUfFI-BECK-PECCOZ, R.: La modernizzazione..., op. cit., pp. 169-174.

20. Un argumento que se considera fundamental para la erradicación del llamado matrimonio consuetudinario o de costumbre (al-zawağ al-urfi); s.v. "zawağ» en $E I^{2}$ op.cit, vol. XI, Leiden, Brill, 2002). Esta modalidad ha sido objeto de reciente reforma en el código argelino conforme a art. 11. "Les conditions de fond relatives à la validité du mariage sont régies par la loi nationale de chacun des deux conjoints» y considerado también, a través del art. 1565, por las reformas de la Moudawwana marroquí recientemente, con el fin de evitar equívocos en cuanto a la determinación del periodo de embarazo de una mujer, en atención al reconocimiento de la paternidad. Sobre las analogías entre los distintos códigos o Estatutos Personales véase Ruíz DE Almodóvar, C.: "Estudio comparado de los Códigos Magrebíes del Estatuto Personal», en Gemma Martín Muñoz (ed.): Mujeres, democracia y desarrollo en el Magreb, Madrid, Martín Muñoz, 1995, p. 204. 
maliki es preceptivo que no se den circunstancias que contrasten con la razón, tales como la concepción de un hijo mientras uno de los cónyuges se encuentra alejado físicamente del otro por grandes distancias durante un tiempo prolongado, en el que se considere inviable la relación conyugal.

Comoquiera que la relación de filiación no surge sino en virtud del reconocimiento en caso de relaciones ilícitas, la legislación prevé que el marido pueda asumir su responsabilidad sobre el niño nacido en el matrimonio al sexto mes de la conclusión del contrato, incluso del concebido antes de la celebración de aquel; es más, atendiendo al interés del niño cabe incluso el reconocimiento de la paternidad respecto a la mujer con la que no ha mantenido relaciones íntimas. Un supuesto que se extiende a los casos en los que ha fallecido el marido, o el repudio impide reconocer la evidencia de las relaciones; así las cosas los herederos del hombre tendrán la obligación de reconocer al niño, atendiendo al término máximo de la gestación -un año-, y al principio de la necesaria legitimación de la filiación paterna, propia de la escuela malik ${ }^{21}$. Para evitar situaciones extremas se intenta erradicar la aplicación de la teoría del niño dormido, como queda expresamente enunciado en el Código Kuwaití, fijando el plazo de un año como máximo de embarazo 22 .

El código argelino, modificado recientemente en parte de su articulado $^{23}$, y en concreto en materia de filiación (art. 8), establece ahora en el art. 13 bis. que la filiación y el reconocimiento de la paternidad, así como su negación, se

21. En este supuesto se suscita la cuestión sobre la paternidad biológica del marido, ya que el nacimiento suele acontecer más allá del término máximo, y por tanto el niño será fruto de relaciones ilícitas. Al margen de esta consideración otras escuelas, y concretametne la escuela lanafi-vigente en Turquía, Siria, Iraq, Egipto, Asia central, Afaganistan, y los sunníes de Pakistan, India y China, así como en Turquía y Argelia, en convivencia con la escuela malikí-, impera el criterio de que el padre y la madre que aún no han contraído matrimonio puedan mantener relaciones lícitas al realizar el coito por error;puede suceder cuando el hombre, habiendo contraído matrimonio con una mujer yazca, con otra por confusión, o bien se une por error con una mujer extraña -como sostiene la escuela hanbalí-. En estos casos la causa del reconocimiento viene dado por las relaciones lícitas que justifican la relación paterna, incluso ante el supuesto de coito por error; mientras que el modo de hacer valer el nasab consistirá en la prueba o manifestación externa del mismo. Estos supuestos pueden darse también respecto a personas que procedentes de alguno de estos países y viviendo en España hagan remisión a su ley nacional, lo que obliga a analizar el derecho sustantivo propio de cada país. AlLufFI-BECK-PECCOZ, R.: La modernizzazione..., op. cit., p. 174. También con caracter monográfio aborda estas cuestiones NASIR, J.J.: The Status of Women under Islamic Law and under modern Islamic Legislation, London, Graham and Trotman, 1990, pp. 45-60. Texto legislativo del año 1984; véase Ruíz-Almodóvar, C.: «El código Kuwaití de Estatuto Personal», Miscelánea de Estudios Árabes y Hebraicos, (en adelante M.E.A.H.), 47 (1998), pp. 335-381.

22. En este sentido es preciso señalar que el período mínimo del embarazo es de seis meses lunares y el máximo es de trescientos sesenta y cinco días.

23. Concretamente en relación a la filiación regulada por el antiguo art. 8, la Ley núm 05-10 de 20 de junio 2005 modificó la Ordenanza núm. 75-58 de 26 septiembre 1975, modificada y completada en materia de Derecho civil, en Journal officiel (JO), 2005-06-26, n 44, pp. 14-20, Secrétariat général du gouvernement, Algérie (consultado el 22-08-2005). Esta materia es objeto de desarrollo en el Decreto ejecutivo núm 96-259 de 29 de julio de 1996 por el que se crea un Comité nacional para la preservación y promoción de la familia. 
someten a la ley nacional del padre en el momento del nacimiento del niño. De manera que si el padre fallece antes del nacimiento del niño la ley que se le aplique será la que le fuera aplicable en vigor en el momento del deceso.

El hijo legítimo es reconocido por el padre mediante distintos signos y actos que evidencian y dan publicidad a su paternidad; la imposición del nombre, tasmiy $a^{24}$, a los siete días del nacimiento es uno de los actos que se celebran con carácter festivo para todos los miembros de la familia y la Comunidad islámica y que, como tal, comporta no solo la imposición de aquél sino también la incorporación de un nuevo musulmán a la Comunidad. Prueba de todo ello es el hecho de que la tasmiya se efectúa sobre el recién nacido por el padre o alguna persona de autoridad ${ }^{25}$. La celebración de estos actos recibe el nombre de 'aquiqa siendo acto recomendable (mustahabb o sunna), y comporta además cortar un mechón de pelo - de ahí el término que designa el acto-y sacrificar una víctima.

En realidad se trata de un ritual que comienza con el bi-'smi llāh o invocación del nombre de Alà que se pronuncia al oído del recién nacido para luego hacer la llamada a la oración -el adān ${ }^{26}$-, o cualquier otra fórmula pía aceptada por la costumbre, y tras una breve alocución se impone el nombre. Un nombre propio, ism 'alam, que viene acompañado de una serie de partes principales impuestas al tiempo de la tasmiya del neonato ${ }^{27}$. La kunya -en español alcurnia-indica la relación de paternidad y se expresa con Umm para la madre y $A b \bar{u}$ para el padre; kunya que alude al honor que da entre los musulmanes la paternidad, y que puede ser ficticia u honorífica. Otro elemento principal del nombre, en esta fase inicial de reconocimiento de la paternidad, es el nasab ${ }^{28}$, o relación de

24. S.v. «Basmala» en $E I^{2}$, t.I, Leiden, Brill, 1986, pp. 1084-1085; la frase es una invocación a Allāh «bism llāh 1-rahmāni 1-rahịmm», que significa "En nombre de Dios el Clemente el Misericordioso», conforme a la alocución de Corán, XXVII, 30. MAílLo SALGADO, F.: Diccionario de derecho islámico, op. cit., pp. 162-163.

25. La imposición del nombre y los apellidos es un ritual ajeno al carácter civil dispuesto en otros sistemas jurídicos, como es el caso del español, tal y conforme se deduce de lo contendio en la Ley 40/1999, de 5 de noviembre, sobre nombre, apellidos y orden de los mismos, que modificaba el art. 109 del C.C.

26. Cabe también cualquier otra fórmula pía, conforme a la costumbre del lugar. Antigua costumbre es la 'aqìqa consistente en el corte de un mechón de pelo del recién nacido y el sacrificio de alguna víctima. Como es costumbre también se suelen hacer regalos, convite y fiesta familiar. PAREJA, F.: Islamología, Madrid, Razón y Fe, 1952-1954, vol. II, pp. 547-548.

27. Entre las muchas posibilidades cabe hacer alusión mediante el nombre a situaciones, hechos y características que se desean reconocer en el neófito. Nombres que en la antigüedad hacían referencia a cosas duras, ásperas, fuertes, o de buen augurio contra los enemigos. A los esclavos se les imponían nombres de cosas agradables. Incluso se asignaron nombres bíblicos citados en el Corán o nombres teóforos o asimilados, caso de 'Abd Allah que significa siervo de Alá, siervo del Misericordioso.

28. El nasab designa el principio fundamental de organización de la sociedad árabe, y alude a la genealogía y relación entre los individuos; s.v. «nasab», $E I^{2}$, vol. VII, Leiden-Nueva York, Brill, 1993, pp. 967-968. 
filiación que se expresa con los términos ibn-o bin-y bint; en ocasiones con sentido metafórico ${ }^{29}$.

Entre las partes secundarias del nombre destacan: el lacab o epíteto de origen popular y descriptivo, mediante el que se pueden exponer características físicas del neonato y morales, e incluso anomalías; la nisba, que como extensión de la idea de filiación alude a las relaciones genealógicas, étnicas o geográficas del recién nacido. Y finalmente, nombres de profesión u oficio, ism mansab, del padre o antecesores por vía masculina.

Cabe también la posibilidad de determinar la filiación judicialmente, al igual que sucede en otros sistemas jurídicos ${ }^{30}$, aún en contra o con la oposición del padre, pudiendo el hijo ostentar el apellido el progenitor si lo solicita el mismo o su representante legal. Tal situación además, no afecta al derecho de velar por los hijos y prestarles alimentos, cumpliendo así con los deberes inherentes a la citada institución $\mathrm{Y}$ del mismo modo la privación de la patria potestad puede ser adoptada mediando decisión judicial, y la devolución de este derecho se efectuará por la misma vía, es decir previa sentencia por pronunciamiento judicial.

\section{LAS OBLIGACIONES INHERENTES A LA PATERNIDAD: VELAR POR LOS HIJOS Y PROCURAR SU SUSTENTO}

Conforme a lo dispuesto en otros sistemas jurídicos ${ }^{31}$ los deberes de velar y alimentar a los hijos son inherentes a la propia filiación, y como tales son exigibles ante los tribunales en situaciones de ruptura y divorcio de matrimonios mixtos $^{32}$.

Las obligaciones son enumeradas en los Codigos de Estatuto personal de forma unánime, si bien con las matizaciones y peculiaridades de los distintos textos vigentes, y a tenor del modelo codificador que los inspira. Así por eljemplo, el Derecho marroquí expresamente a través de su artículo 52 bis de la Mudawwana ${ }^{33}$ establece que la guarda del niño forma parte de las obligaciones sometidas a la carga del padre y de la madre mientras que se encuentren unidos

29. Así sucede con términos impuestos como ibn ul-sapì, que significa hijo del camino, viandante o peregrino. Es de uso corriente la abreviación de Ibn con una sola b. PAREJA, F.: Islamología, op. cit., p. 547.

30. Según lo dispuesto en el art. 111 C.C.

31. SEOANE PRADO, J.: «Prestaciones económicas: Derecho de alimentos y pensión compensatoria» en Tratado de Derecho de Familia, op. cit., cap. VI, pp. 365-442.

32. El art. 110 C.C. reconoce estos deberes y ha de ser considerado en atención a los supuestos de ruptura familiar en matrimonios o parejas no matrimoniales con hijos menores; los alimentos corrspondientes a los hijos ante tales procesos se exigirán desde la fecha de la demanda, conforme a lo dispuesto en el art. 148 C.C.; el juez estará a lo dipuesto en el art. 768 de la Ley de Enjuiciamiento Civil sobre la adopción de medidas cautelares. Sobre la materia reguladora de estos supuestos y la jurisprudencia véase CALVÉ CORBALÁN, C.: "Filiación», en Tratado de derecho de familia, op. cit., cap. IV, pp. 235-236.

33. Dahir $n^{\circ} 1-04-22$ du 3 février 2004 portant promulgation de la loi $n^{\circ} 70-03$ portant Code de la Famille. Bulletin officiel, 2005-10-06, n 5358, pp. 667-701. Con especial mención a las disposiciones sobre matrimonio, divorcio, nacimiento y sus efectos, la representación legal, el testamento 
por los lazos del matrimonio; la guarda del niño se confía prioritariamente a la madre y después al padre y a la parentela materna y paterna conforme a reglas determinadas ${ }^{34}$. No en vano, la madre es quien debe proveer de alimento al niño desde el momento de su nacimiento, conforme al texto coránico ${ }^{35}$, al margen de la pervivencia del contrato matrimonial entre los cónyuges, o de la rescisión del mismo en virtud del divorcio consensual ${ }^{36}$.

En este mismo sentido, los cambios que se han producido en la legislación maroquí sobre la materia prevén -debido según algunos autores a la influencia de la escuela hanafi- que la mujer que ejerce la hadăana pueda reclarmar una remuneración distinta a la de la nafaqa -a la que está obligado el padre hacia el hijo (arts. 103-104)- incluso en caso de separación del esposo. La institución de la guarda del menor ha sido objeto de sucesivas reformas, ya que si bien en los textos originarios se supeditaba hasta la mayoría de edad o la emancipación, en la actualidad la guarda se extiende en el caso de los niños hasta la edad de 12 años y hasta los 15 años para las niñas, conforme a lo dispuesto en el art. 102 de la Mudawwana ${ }^{37}$. Si bien, más allá de este período el niño puede elegir entre residir en casa de la persona a su elección que puede ser su padre, su madre u otro pariente mencionado en el artículo 99 del mencionado texto. Este artículo hace referencia a la capacidad de elección por parte de los niños; un supuesto que por ser ajeno a los valores de la sociedad musulmana se ha puesto en tela de juicio por parte de la doctrina ${ }^{38}$.

y la sucesión. Prevé, también, la determinación de la responsabilidad conjunta de los esposos respecto a los hijos habidos de su unión y confirma la igualdad entre hombre y mujer en cuanto a la edad para contraer matrimonio.

34. Mudawwana, Lib.III. De la filiación y sus efectos. Cap. III La custodia del niño (hadāna), art. 99. Al padre, a la abuela materna del niño, a la madre de su abuela materna, a su tía materna germana, a su tía materna cosanguínea, a su tía materna uterina, en a su abuela paterna, a la bisabuela paterna del niño, en una u otra línea donde el padre es probado, y en defecto, hasta el infinito en esta mismas líneas; a la hermana del niño, a su tía paterna, a su tía paterna del padre del niño, a la tía materna del padre del niño, a su sobrina por parte de hermano, a su sobrina por una hermana, a su hermano, a su abuelo paterno, a su sobrino carnal por un hermano, a su tío paterno. En todos estos casos, el padre hermano tiene prioridad sobre el uterino y este último sobre el cosanguíneo.

35. Cor. II,233.

36. Esta circunstancia es analizada conforme a la propuesta de las distintas escuelas jurídicas por NASIR, J.J.: The Islamic Law, op. cit., pp. 170 y ss.

37. Desde el punto de vista histórico la fijación de esta edad para la mujer venía condicionada a aquella en la que se considera hábil para consumar el matrimonio; parece ser que los andalusíes respetaban por tradición los nueve años en las féminas, como queda constatado en las Leyes de moros. A partir de ese momento el padre está obligado a la nafaga de la hija, por un plazo máximo de siete años después de la consumación -que por regla general podía tener lugar a los nueve años-. La tutela voluntaria del padre durante ese periodo está justificada en base a la tradición, ya que esta fue la edad a la que el Profeta casó con 'Aicha, según las tradiciones de Al-Buhââî (AL-BuHĀRĪ: Op.cit, t. II, p. 568). Sobre este supuesto véase Leyes de moros, op. cit., tit. CCCVIII, cap. XXXVII, p. 337. En relación al ejercicio de la tutela por el padre una vez consumado el matrimonio véase IBN ‘ĀṣıM: Op. cit., v. 1339, p. 721

38. Idem, art. 102. 
Esta situación se hace compatible con aquella otra que prevé que, planteado el caso de la elección al joven, será preferible la permanencia bajo tutela hasta su emancipación o la mayoría de edad (art. 165) siempre y cuando el tutor, explícitamente, justifique que es apto para ser liberado de la tutela y se hayan cumplido las formalidades legales establecidas a tal fin. Cualquier desacuerdo en relación al reconocimiento de la capacidad entre el menor y el tutor se someterá al juez, como así mismo se prevé en otros ordenamientos jurídicos del mismo ámbito geográfico.

El derecho argelino, a través de su art. 65 prevé el ejercicio de la guarda por parte de la madre, si bien reserva la formación religiosa del niño a favor del padre, al menos hasta que cumpla diez años, en el caso de los niños, y hasta la edad del matrimonio, para el caso de las féminas, salvo que se den circunstancias especiales que precisen la intervención judicial. Así por ejemplo, la reciente reforma del Código de Estatuto personal argelino en materia de guarda por parte de los padres regula la intervención del juez para determinar la competencia del padre, la madre y en defecto de estos de los abuelos sobre el menor ${ }^{39}$. La legislación argelina prevé, también en su legislación sobre familia, a través del art. 20 que son los padres los titulares del deber de cuidar y alimentar a los hijos $^{40}$, estando obligados a esta tarea por el Estado y los entes públicos. Un deber que, en el caso de abandono del menor, comporta la consideración de delito y atentado contra los derechos elementales de aqué $1^{41}$.

En algunos países magrebíes, caso de Túnez y Marruecos, los supuestos de ruptura matrimonial son abordados en base a la doctrina de la escuela maliki, incorporando algunas modificaciones inspiradas en la doctrina de la escuela hanafi. En este sentido el código tunecino (art. 67) limita la duración de la custodia por las mujeres a los siete años para el caso de los chicos y de los nueves años para las chicas, cuando muchos de los países seguidores de la escuela citada han abandonado ya esta regla, como es el caso de Túnez mediante reciente reforma ${ }^{42}$.

En este sentido el Código tunecino en materia de custodia del menor, mediante el art. 67 (Modificado por la ley n. 49 de 3/6/1996 y por la ley n.74 de 12/7/1993) establecía que cuando el matrimonio se rompe por muerte, la custodia se confía al cónyuge superviviente. Por otro lado, si el matrimonio se rompe y ambos cónyuges están vivos, la custodia se confía bien a uno de los dos, bien

39. Véase art. 65 Loi n. 84-11 du 9 juin 1984 portant Code de famille, Journal officiel de la Republique Algerienne democratique et Popolaire, y respecto a la guarda art. 66 bis de Loi n $2006-10$ du 6 mars 2006 complétant les dispositions du Code du statut personnel. Journal officiel, 2006-03-10, n²0, p. 532., respecto Code du statut personnel du 13 août 1956, al (TUN-1956-L-73374).

40. BenmelHa, G.: «L'obligation alimentaire en droit interne», Revue Algériene des Sciences Juridiques (en adelante RASJP), 21 (1984), pp. 799-831.

41. AsLAOUI, L: "Le statu juridique de l'enfant au Magreb», RASJP, 28 (1990), pp. 241-257. Y sobre la guarda del niño, BENCHEIKH Hocine DeNNOUNI, H.: "La garde: un attribut de la maternité en droit Algérien", Revue International du Droit Comparé, 38 (1986), pp. 897-917.

42. Sobre protección menor en Túnez reciente reforma Code de la protection de l'enfant - Y desarrollado por Loi nº 2006-35 du 12 juin 2006. 
a otra persona. En estos casos el juez, al adoptar la decisión, tiene que considerar el interés del custodiado; y la madre, en el caso de que se le haya confiado la custodia, goza de las atribuciones de la tutela (wilāya) en lo que concierne a los viajes, estudios y administración de las cuentas financieras del custodiado.

Regula también dicho Códigola contribución y participación de la esposa en los gastos del hogar. Así en virtud del art. 23 -modificado por el mismo texto legal anteriormente citado-, cada uno de los cónyuges debe tratar al otro con benevolencia, tener buenas relaciones con él y evitarle sufrir perjuicio. Ambos colaborarán en la marcha de los asuntos de la familia, la buena educación de los hijos y la gestión de los asuntos de estos últimos que comprende la enseñanza, los viajes y las transacciones financieras. Y el esposo, en su condición de jefe de la familia, deberá asumir los gastos de la esposa y de sus hijos, según su situación y la situación de ellos, en el marco de las obligaciones propias de la manutención (nafaqa). La esposa, por el contrario, solo participará en los gastos familiares si posee bienes ${ }^{43}$.

La manutención de los hijos se prolonga hasta que alcancen la mayoría de edad o, después de ésta, hasta que finalicen sus estudios, a condición de que no sobrepasen los veinticinco años. Un derecho que en el caso de las féminas continúa mientras no disponga de recursos para mantenerse o su manutención no sea obligación de su esposo. Así mismo subsiste el derecho de manutención de los hijos impedidos o incapaces de mantenerse sin tener en cuenta su edad. En ambos casos obligan al padre, al tutor y a la madre, en la medida que establezca la ley (art. 60).

El código marroquí adopta análogos criterios ${ }^{44}$ y prevé la situación de indigencia del padre que, conocida por el juez, supondrá la prohibición de la alienación de los pocos bienes que conserve, especialmente de los inmuebles.

Estos criterios se han extendido a otros países bajo la influencia de la escuela malikí, como es el caso de Senegal que se rige por idénticos principios, tal y conforme queda reflejado en la legislación promulgada sobre la materia ${ }^{45}$. La edad sobre la que se ejerce la guarda y custodia dentro del matrimonio es la de los 21 años, sin que ello sea inconveniente para que los chicos puedan contraer matrimonio a los 20 años y las chicas a los 16; e incluso por debajo de esa edad, en la que el padre o tutor ejerce la custodia y previa autorización judicial ${ }^{46}$. En

43. En el caso del código argelino conforme al art. 12. los efectos personales y matrimoniales del matrimonio se someten a la ley nacional del marido al momento de la conclusión del contrato matrimonial; de esta manera la disolución y separación de los cuerpos se someterá a la ley nacional de los esposos, en el momento del acto de presentación de la instancia.

44. En concreto a través del Libro IV. De la capacidad y de la representación. Capítulo IV. De la representación legal. Art. 148 y ss del texto primigenio.

45. Senegal a partir del año 1961 inició un proceso de reforma del Estatuto Personal, que concluyó en 1972 mediante la publicación el 1 de enero de 1973 del Family Code que regula las instituciones del matrimonio, divorcio, sucesión y custodia, con una sección dedicada al Derecho sucesorio islámico. http://www.gouv.sn/textes/const_detail.cfm?numero=TITREII

46. En cualquier caso, el matrimonio contraído por un menor, sin consentimiento, previo será nulo. 
materia de guarda y custodia se garantizan esos mismos derechos a favor del niño y en caso de separación de los cónyuges mediando sentencia judicial; en cualquier caso, será el padre quien ejerza esta obligación, salvo que sea declarado incapaz para tal ejercicio.

La escuela malikí en Kuwait reconoce el derecho a las madres de mantener la custodia de los hijos e hijas hasta la pubertad, para los varones, y hasta el casamiento para las féminas. Cabe también la posibilidad de que tal derecho lo ejerza una mujer no musulmana pero en ningún caso le estará permitido al custodiado permanecer con ella después de haber cumplido los siete años. La custodia por las mujeres finaliza para el joven con la pubertad -en concreto hasta que el niño adquiera la capacidad de razonar $\left(r u s ̌ d^{47}\right)$ y sea capaz de comprender los principios del Islam-, y para la joven con su matrimonio y la consumación del mismo ${ }^{48}$.

En realidad todos estos supuestos y derechos reconocidos a favor del menor forman parte de una institución clásica en el Derecho islámico: la hadāna o el derecho de custodia de un niño, extensión de la guarda que como regla ejerce la madre o cualquier otra persona de sexo femenino por línea materna, y que solo en determinadas circunstancias revierte a favor del padre o de otra persona de sexo masculino dentro de la línea paterna ${ }^{49}$. Tal derecho comienza en el momento del nacimiento del bebé, indistintamente macho o hembra y mientras los padres vivan juntos, constituyendo una prerrogativa de la mujer, incluso antes de la disolución del matrimonio. Tan solo bajo dos supuestos cabe que el padre asuma ese derecho sobre la mujer: cuando el marido permite a la mujer viajar lejos de domicilio conyugal para visitar a sus parientes -como así prevé la escuela hanafi, mientras que las escuelas maliki y hanbali solo reconocen esta posibilidad para los casos previstos en las cláusulas matrimoniales-, o bien cuando el marido decide, de forma temporal, llevar al niño consigo a un viaje sin que le acompañe su esposa.

De ello se deduce que el marido no puede viajar o separar al hijo de su madre sin su autorización, salvo en situaciones en las que se ponga en peligro su persona o su condición de musulmán, como se ha puesto de relieve a lo largo de la historia ${ }^{50}$. Si la mujer que tiene la custodia no es musulmana, tiene derecho a

47. S.v. «rušd» en MAíllo SAlGADO, F.: Diccionario de derecho islámico, op. cit., p. 328.

48. En relación a este supuesto existe una tradición recogida por Al-Buhânî, en la que se hace alusión al matrimonio de `Aicha con el Profeta, cuando la primera contaba tan sólo seis años; al respecto véase EL-BoKHĀRİ: Les traditions islamiques, t. III, chap. XXXIX, p. 568. En relación a la licitud del matrimonio de la mujer antes de la pubertad véase Corán, LXV, 4. Sobre este mismo asunto véase voz «nikāh» en $E I^{2}$, vol VIII, Leiden, Brill, 1995, p. 29.

49. El término técnico en el lenguaje de los fuqahā' es hiḍana con el significado explicado en el texto.

50. Una situación análoga fue presentada por un padre que residente en Tlemencen en época andalusí reclamó la separación de su hija de siete años de la madre, pues estaba en peligro su condición de musulman, ante la presión ejercida por los cristianos en época nasri; véase MARIN, M. y EL-Hour, R.: "Captives, Children and conversion: a case from late nașri Granada», Journal of the Economic and Social History of the Orient, 41:4 (1998), pp. 453-473. 
ejercer la custodia del niño musulmán hasta que éste pueda comprender la religión o se tema que corra peligro su formación fuera del Islam ${ }^{51}$. Y aún a pesar de estos supuestos, los países en los que rige la escuela šaf'ii y hanbali reconocen la posibilidad al adolescente de que, llegada la pubertad, pueda expresar su deseo de independizarse de su padre o madre, si bien lo recomendable (makrūh) es que permanezca con sus padres.

Una cuestión controvertida es la ponderación de la naturaleza de la hadāna en cuanto derecho del padre o derecho del niño. En este sentido la doctrina determina que, si bien es un derecho que debe ejercer la madre o el padre, es ante todo un derecho del niño, y solo en atención de su interés se definen las condiciones en las que debe ejercerse ${ }^{52}$. El ejercicio de la hadāna por parte del marido solo es factible en supuestos determinados, ante la ausencia de la madre o si ella es declarada incapaz para asumirla o se le ha denegado este derecho; en estos casos la custodia la ejercerá las hermanas de la madre las hermanas uterinas, antes que la consanguíneas; seguidamente las sobrinas -a excepción de las consanguíneas que están relacionadas con el niño por vínculo solo del padre-y las tías maternas con preferencia a las paternas. De igual modo, las escuelas hanafi y mäliki reconocen al padre ese mismo derecho solo en defecto de todas las féminas relacionadas con los grados prohibidos para contraer matrimonio. El hombre es ante todo el 'ạsabat o parientes de línea masculina que concurren

51. En estos casos conceptos como hadāna, tafrīq-derecho del padre a separar al hijo de la madre-y $i t h q \bar{a} r-$ periodo en el que se ejerce la guarda sobre las niñas, pasada la primera infancia- son objeto de análisis por la doctrina, que en el caso de la escuela malikí permiten la permanencia con mujeres de religión no islámica. El Derecho islámico a lo largo de la historia ha observado circunstancias especiales, tales como la celebración de esponsales con hijas impúberes o menores de edad; esta posibilidad comportaba aplazar el perfeccionamiento del contrato hasta el momento en que la prometida pueda consumar el matrimonio Existe divergencia de opiniones sobre el valor de la consumación del matrimonio en atención a la perfección del contrato, ya que para muchos autores el contrato matrimonial es perfecto desde que se produce el intercambio de consentimiento. Sobre el matrimonio en la etapa andalusí. En relación con las fuentes y el tratamiento de esta institución véase VILA, S.: "Formulario notarial de Abenmoguit», A.H.D.E., 8 (1931), p.16 y del mismo autor «Un contrato de matrimonio entre musulmanes», A.H.D.E., 10 (1933), p. 187; en este último artículo se abordan cuestiones relativas a la dote y derechos de la mujer en relación al cumplimiento de la misma por el marido; de un momento posterior pero de gran utilidad es el estudio y presentación de unos contratos matrimoniales en los que inicialmente se hace alusión a su condición de "contratos de esponsales» y que han sido presentados por LABARTA, A.: "Contratos matrimoniales entre moriscos valencianos», AL-Qantara, 4, fasc.1 (1983), pp. 64-65; asimismo es destacable el estudio de LONGAS, P.: Vida religiosa de los moriscos, ed. facs., Granada, Universidad de Granada, 1990, pp. 273-283 y del mismo modo IDRIS, H.R.: "Le mariage en Occident musulman. D'après un choix de fatwâs médiévales extraites du Mi'yâr d'Al-Wanšarî̌ŝ̀̀, Studia Islamica, 32 (1979), pp. 157-167; remítase el lector a los estudios de CARMONA GONZÁLEZ, A. en "Aportación al estudio del contrato matrimonial en el Occidente islámico medieval», Miscellanea Arabica et Islamica. Dissertationes in Academia Ultrajectina prolatae, anno 1990, 52 (1993), pp. 53-66; y finalmente con carácter general véase GAUDEFROY-DEMONBINES, M.: Les institutions musulmanes, Paris, 1921, p. 122. El tratamiento de la institución conforme a los presupuestos de la escuela malekí y šaf'ii en SANTILLANA: op. cit., t. II, p. 226. Véase también la opinión de juristas malikíes, y en concreto las referencias de Ibn Sahl, en MARIN, EL-HouR: "Captives, Chindren and conversión", op. cit., pp. 464-465.

52. s.v. «hadāna», en $E I^{2}$, vol. III, op. cit., p. 17. 
en el mismo orden que en materia de sucesión: primeramente, el padre; en ausencia de cualquier 'ạșib, la escuela hanafi hace un llamamiento a los hombres por línea femenina pero solo a aquéllos respecto a los que está prohibido el matrimonio, si se trata de la custodia sobre una hembra; finalmente se llama a hombres y mujeres con los que no hay impedimento de grado para contraer matrimonio, ejerciendo los hombres la custodia sobre los chicos y las mujeres sobre las chicas. Para el caso de ausencia total de parientes que puedan ejercerla será el qā dì quien determina la persona de confianza-.

Estos presupuestos son regulados en la escuela šaf'i $i$ hanbalī, aunque prevén el ejercicio por parte de la mujer en menor medida pudiendo el varón asumir la custodia, incluso si existen mujeres de grado próximo al menor. En estos supuestos, ante la ausencia de la madre y de ascendientes femeninas-e incluso si estas son apartadas o consideradas incapaces para ejercer este derecho-, la lä̈...na la asumirá el padre y seguidamente sus ascendientes femeninas. También estas escuelas presentan como particularidad el que la hermana consanguínea sea preferida a la uterina y la tía paterna a la materna.

Los Estatutos y Códigos personales han introducido ciertas reformas respecto al Derecho islámico tradicional. Así por ejemplo, los países de tradición hanafi se han ocupado de extender el periodo de custodia y guarda del menor más allá de los límites establecidos por el Derecho islámico tradicional. Egipto es uno de los países en los que prima la escuela hanafi y sobre esta materia las reformas acaecidas en 1929 reglamentaron la posibilidad de que el juez, por razón del interés del niño, extendiera este periodo de custodia más allá de los nueve años para el niño y de los once para las niñas, si bien las últimas reformas acaecidas en este país prolongan este periodo de custodia y guarda hasta los diez años para el caso de los chicos y a los doce para las chicas, respecto al ejercicio de la misma por parte de la madre divorciada. Ello no obsta para que el juez extienda esos derechos hasta los quince años para los jóvenes y la edad del matrimonio en el caso de las féminas, cuando las circunstancias así lo requieran ${ }^{53}$. Igual criterio se siguió en el caso de Jordania ${ }^{54}$ (1951, art. 123) y Siria ${ }^{55}$ (1953, art. 147), países seguidores de la misma escuela jurídica. En el caso de Jordania el matrimonio contraído por mujeres menores de dieciocho años con

53. Nótese que la edad mínima para el matrimonio se sitúa en los 18 años para el caso de los chicos, y en los dieciseis para las chicas. En cualquier, el juez es competente para autorizar el matrimonio en aquellos casos en los que el wali rechace esta posibilidad, conforme a las últimas reformas del Personal Status (Amendment) Law, núm.. 100/1985, reformado el 27 de enero 2000; véase http://www.law.emory.edu/IFL/legal/egypt.htm. Y sobre la institución del matrimonio y sus efectos en Egipto, conforme a las nuevas reformas véase: EL ALAMI, M.: «Law no. 100 of 1985 Amending Certain Provisions of Egypt's Personal Status Laws», Islamic Law and Society, 1:1 (1994), pp. 116-136; NAJJAR, F.: "Egypt's Laws of Personal Status», Arab Studies Quarterly, 10:3 (1988), pp. 319-345.

54. El texto del año 1976 en Ruíz Almodovar, C.: «El Código Jordano de Estatuo Personal», M.E.A.H., 46 (1997), pp. 3-418.

55. Véase Ruíz Almodóvar, C.: «El Código Sirio de Estatuto Personal», Miscelánea de Estudios Árabes y Hebraicos, 45 (1996), pp. 3-378. 
varones que superen los 20 requerirán autorización especial, como también se precisa el consentimiento de quien ejerza la custodia en los supuestos de matrimonio entre chicas menores de dieciocho años, salvo en el supuesto de las féminas que superen esa edad y sean divorciadas o viudas; y ello considerando que es hasta esa edad en la que se ha de ejercer la custodia pero sin eliminar la posibilidad de que el juez, ante circunstancias especiales, autorice el matrimonio de chicas menores de esa edad ${ }^{56}$.

El Código sirio en su legislación sobre estas cuestiones considera que el periodo de custodia finaliza al cumplir el joven nueve años de edad y la niña a los once años ${ }^{57}$. Si el tutor no es el padre, el juez puede entregar al hijo, niño o niña, al que sea más apto entre la madre, el tutor o quien ocupe el puesto de ambos hasta que la niña se case o llegue a la pubertad y hasta que el niño alcance la mayoría de edad. Determina las obligaciones del padre respecto al hijo en caso de repudio ${ }^{58}$. Si en el repudio por compensación se exige como condición que el esposo no pague la remuneración de la lactancia del niño o que su madre lo conserve con ella, manteniéndolo durante un tiempo determinado, y la esposa se vuelve a casar o abandona al niño, el esposo recupera de la esposa lo que equivalga a la remuneración de la lactancia o de la manutención del niño durante el tiempo restante. En otro orden de cosas, si la madre es indigente en el momento del repudio por compensación o llega a ser indigente después, el padre está obligado a pagar la manutención del niño y la madre contrae una deuda con él.

Asimismo, el citado código reconoce el derecho de la mujer a la custodia de sus hijos, que no prescribe a causa de su trabajo siempre y cuando garantice la protección y el cuidado de ellos de modo válido. En el supuesto de separación o divorcio, la persona que ejerza la custodia, bien sea la madre o la abuela materna, podrá solicitar ante el juez la entrega del menor, siendo el juez quien decida esta cuestión tras cerciorarse del parentesco por medio de documento acreditativo expedido por la Secretaría del registro civil; en este mismo sentido deberá decidir quien asumirá la manutención temporal del menor.

No obstante ello, la madre tiene una serie de limitaciones, y entre ellas el no poder viajar con su hijo durante la vida conyugal, salvo con autorización de su padre. Asimismo la madre que tiene la custodia, al finalizar su'idda puede viajar con el custodiado sin la autorización del tutor a la población en la que tuvo lugar su contrato matrimonial. Y de igual modo podrá viajar con él por el

56. The Civil Status Law No 9 of 2001. Al-Jarida Al-Rasmiya, 2001, No 4470 y http://www.fidh. org/lettres/130-2.htm.

57. Lib. III, Del nacimiento y sus efectos. Cap. $2^{\circ}$ De la custodia. Art. 139.2. La ejecución de la decisión del juez tendrá lugar por parte del departamento competente para dicha ejecución y quien se oponga a la entrega o a la manutención necesario potencialmente, tiene que presentar en el juzgado competente la demanda de agravio por esta decisión y la demanda se someterá a los procedimientos y medios de la impugnación de las sentencias legales, la presentación de esta demanda no tendrá efecto sobre la ejecución de la decisión mencionada, salvo cuando exista una sentencia firme.

58. Lib. II, De la disolución del matrimonio. Capítulo $2^{\circ}$ Del repudio por compensación. Art. 102. 1. 
interior del país a la población en la que resida o en la que trabaje, cualquiera que sea, a condición de que uno de sus parientes ('aṣaba) en grado prohibido para el matrimonio resida en ella. Derechos reconocidos también a la abuela materna. Y entre las causas para impedir la custodia baste citar la oposición y negligencia de la mujer que tiene la custodia.

En la órbita de los países de tradición hanafi, Iraq en 1959 se ocupó de la materia (art. 57, 5) determinando que la custodia sería ejercida por la madre, en el caso de divorcio de los cónyuges, hasta los diez años, tanto para los chicos como para las chicas. Cabe la posibilidad de extender la hadāna en principio hasta los quince años, pero sin que ello suponga la consideración de un plazo máximo: desde ese momento el chico podrá decidir con quien de sus padres convivir ${ }^{59}$.

En Sudán las reformas se realizaron por vía de la Circular núm 34 (1932, art. 1) en virtud de la cual, y siguiendo la escuela malikí los niños permanecerán bajo la custodia de las mujeres hasta la pubertad, y las niñas hasta la consumación del matrimonio. Además, la citada legislación sudanesa prevé la custodia por una mujer de diferente religión, concluyendo este derecho cuando el niño alcanza los cinco años, con el fin de evitar que éste se instruya en una religión distinta a la del Islam ${ }^{60}$.

\section{LA NEGACIÓN DE LA PATERNIDAD}

Al margen de los supuestos legalmente establecidos para atribuir y reconocer la paternidad, caben otros supuestos, también legales, que han sido objeto de revisión en las últimas décadas, por la indefensión que para la madre y el niño puedan ocasionar. La negación de paternidad, li'ān, es, además de motivo de repudio, una modalidad tradicional en el Derecho islámico que sin duda genera no pocos perjuicios respecto a los derechos de la mujer y el niño en los países en los que durante siglos se ha ejercido ${ }^{61}$.

El li'ān se pronuncia ante el juez, quien de inmediato ordenará la separación de los cónyuges. Se trata de una anulación tiene carácter irrevocable y, en modo alguno tiene carácter de divorcio. El marido mediante este supuesto se reserva el derecho a negar la paternidad sobre el niño nacido de su esposa, existiendo constancia por su parte de no ser fruto de la unión con aquella. Este supuesto precisa del testimonio de cuatro testigos requeridos para acusar de adulterio a

59. Aspectos regulados en la Ley sobre Cuidados del menor núm. 78/1980 y Ley sobre el derecho de custodia de la madre núm. 106/1987; http://www.law.emory.edu/IFL/legal/iraq.htm.

60. La custodia del menor en Sudán, a la luz de la tradición islámica y su pervivencia pese a movimientos posteriores de reconocimiento de los derechos de la mujer, fue abordada por FLUEHRLobBan, C.: "Issues in the Shari'a Child Custody Law in the Sudan", Northeast African Studies, 4 (1984), pp. 1-9.

61. Se trata de una de las modalidades del talak, s.v. en $E I^{2}$, vol. X, Leiden, Brill, 2000, pp. 151-158. Un análisis sobre la evolución del Derecho privdo sudanés en GUADAGNI, M.: «La riforma del diritto privato nel Sudan: uno studio sui modelli normativi nel diritto africano", en Raccolta di scritti per il cinquantesimo anniversario dell'Università di Trieste (1924-1974), Trieste, EUT, 1976, pp. 183-198. 
su mujer; si tiene constancia de que no es padre de lo que pueda venir, tiene como único medio de eximirse de la presunción de paternidad el indicado en el Cor. 24/6-9 de jurar cuatro veces su veracidad y de imprecar luego el castigo divino sobre sí si ha acusado en falso. Cuando el padre niega la paternidad mediante juramento, la mujer puede defenderse respecto a la condición del hijo parido como propio con juramento análogo y en tal caso se anulan ambos juramentos.

El Corán no hace referencia a los efectos jurídicos de este acto, a diferencia de la tradición y la doctrina, que prevé el caso en que el marido, hecha la acusación, no quiera confirmarla con el juramento. En este supuesto hay que constreñirle a que jure, con la alternativa de 80 azotes, pena del calumniador. También se ha de castigar a la mujer que no defienda su inocencia. En todo caso quedará disuelto el matrimonio.

El Derecho islámico determina dos categorías de hijos ilegítimos: la primera corresponde al llamado walad al-mulā'ana, es decir, hijo negado -hipótesis que es considerada meramente teórica-, y la segunda hace referencia al hijo fruto de relaciones extramatrimoniales o walad az-zin $\bar{a}$, anteriormente citado. En ambas circunstancias estos hijos no generan lazos de parentesco con el padre ni con la familia de éste, pues la irregularidad de su nacimiento -o mejor de su concepción- le hace ser considerado fruto de la fornicación.

Los efectos inmediatos de la negación de paternidad son la negación del derecho a heredar, la negación del derecho a su mantenimiento y la determinación de nuevos grados de prohibición a nivel de relación entre el hombre y el niño. Sin embargo, respecto a la cuota hereditaria correspondiente al hijo ilegítimo, este heredará de su madre y de todos los parientes de ella, de sus hermanos y hermanas uterinas, como si fuera legítimo ${ }^{62}$.

Desde el punto de vista conceptual interviene en esta materia otro término cual es el de hijo natural, y que conforme al Derecho islámico se da en aquello supuestos en los que el niño no se atribuye automaticante al padre si este reconoce que es fruto de relaciones extramatrimoniales, por parte de la mujer. En el caso en que el padre reconozca a aquél como hijo, no podrá, en modo alguno, manifestar que es fruto de la fornicación o el adulterio. La madre, por el contrario, asumirá por derecho su condición, y desde el punto de los derechos concernientes al niño competerán no solo a ella sino a toda su familia ${ }^{63}$. En definitiva, y según las escuelas ortodoxas, el hijo considerado natural, tiene una familia uterina, que no se limita tan solo a la madre, sino que comprende a todos los parientes ('asaba) de aquélla, sus hermanos y hermanas uterinas. Entre todos ellos existe vocación sucesoria recíproca. De manera que en caso de fallecimiento del llamado hijo ilégitimo sin descendencia masculina, la cuota fija correspondiente herditaria (farḍ) se adjudicará, si los hubiera, a la hija, ma-

62. AIt ZAI, N.: "L'enfant illégitime dans la societé musulmane», Peuples Méditerranéens, 48-49 (1989), pp. 113-122.

63. Véase al respecto CHALABI, E.H., y MEKABECH, C.: "L'enfant conçu et né hors mariage», RASJEP, 25 (1997), pp. 295-312. 
dre, hermanos, hermanas uterinas y ascendientes maternales, con exclusión de cualquier pariente del padre que en su momento negó tal condición.

Es importante aludir a la filiación materna, una posibilidad que no suele plantear controversia, a diferencia de lo que sucede en el caso del reconocimiento de la filiación paterna ${ }^{64}$. No en vano, cabe la posibilidad de que la mujer emprenda acciones para obtener, mediante sentencia firme, la filiación desconocida sobre el hijo habido con un hombre que niega su paternidad, ajustándose la nueva situación a la realidad registral.

Cuando el padre niega la paternidad mediante juramento, la mujer puede defenderse respecto a la condición del hijo parido como propio con juramento análogo y en tal caso se eliden ambos juramentos.

Desde el momento del nacimiento la madre está obligada a los cuidados hacia su hijo, si bien pudiera darse el caso de que la madre no pueda alimentar a su hijo o rechace hacerlo, debiendo en estos casos -así como en caso de fallecimiento de ésta - procurar lo necesario para su alimentación; esta postura, defendida por las escuelas sunnies, no es compartida por los šiies para quienes si la madre rechaza o niega el alimento al niño perderá la custodia sobre el; derecho de custodia que se extiende al niño (hadāna), durante los primeros años de su vida, que comprende también el derecho a ser educado, y a la administración de sus bienes-tanto por el padre como por la madre ${ }^{65}$.

La presunción de paternidad (después de la celebración del matrimonio y antes del plazo legalmente establecido siguiente a la disolución del mismo) es una posibilidad que, al igual que en otros ordenamientos jurídicos ${ }^{66}$, prevé el Derecho islámico. Una de las medidas legales más eficaces para evitar la denegación de paternidad no ajustada a los requerimientos legales es la supresión de la práctica del niño dormido; así se evidencia a través de los distintos códigos de Estatuto personal.

El Código tunecino fija el plazo máximo de embarazo, que para malikíes y šaf'iiss supone para el marido la presunción de la filiación iuris tantum y para los hanafíes iuris et de iure ${ }^{67}$, del hijo nacido durante el matrimonio, siguiendo el principio del al-walad lil-firaš; si bien el período máximo de gravidez materna es de diez meses. Sin embargo la escuela malikí ha defendido durante décadas

64. NASIR, J.J.: The Islamic Law, op. cit., pp. 162-164; y AllufFI-BECK-PECCOZ, R.: La modernizzazione, op. cit., pp. 162-164.

65. NASIR, J.J.: The islamic personal Status, op. cit., p. 173.

66. En este caso el ordenamiento español, a través del art. 116 del C.C. determina que ese plazo es de trescientos días siguientes a la disolución o la separación legal o de hecho de los cónyuges. Por otro lado es medio de prueba suficiente de la filiación presumida la mera presunción de paternidad, conforme al art. 113 C.C. Los cónyuges estarán exentos de probar el hecho presunto, según el art. 385 de la ley de Enjuiciamiento Civil si están de acuerdo con la filiación; mientras que si no es así el cónyuge que la niegue deberá negar la presunción mediante prueba en contrario, y atendiendo a la presunción de separación de convivencia, deal art. 69 del C.C. Véase Calvé Corbalán, C.: Tratado de derecho de Familia, op. cit., cap. IV, «Filiación», pp 236 y ss.

67. CASTRO, F.: "Diritto musulmano e dei paesi musulmani», en Encilopedia Giuridica Treccani, vol. XI, pp. 7-11. 
incluso un período de gestación de tres o cuatro años, mediante la teoría del niño dormido ${ }^{68}$. Un supuesto que ha sido erradicado por un lado mediante la fijación de los periodos de pureza legal 'idda, que se prolonga durante tres meses completos para la divorciada; mientras que en el caso de la viuda ésta deberá observar una 'idda de cuatro meses y diez días completos y la mujer embarazada verá prolongada su idda dura hasta el parto; y por otro mediante la fijación de la duración máxima del embarazo es de un año desde la fecha del repudio o muerte del esposo.

El Código marroquí también aborda esta cuestión en su última reforma ${ }^{69}$. En relación al término del embarazo regula el periodo de 'idda de la mujer embarazada, a efectos de la disolución del matrimonio, y al objeto de evitar la negación de paternidad por parte del marido. Según tal reforma en la que la mujer se someterá a la opinión de expertos para determinar si se encuentra embarazada, y así fijar el plazo máximo de su gestación, que en todo casos será de un año y se efectuará con la mayor precisión posible a fin de evitar cualquier interpretación errónea que pudiera perjudicarla a ella y al hijo que espera ${ }^{70}$.

Entre los textos de inspiración malikí el código jordano puso también fin a la práctica del niño dormido, fijando el plazo máximo del embarazo en un año ${ }^{71}$. El hijo de la esposa de un matrimonio válido o anulable después de la consumación o de la cohabitación válida, si naciera después de seis meses, o más, desde la fecha de la consumación o de la cohabitación válida, su filiación pertenece al esposo; mientras que si naciera después de la separación, su filiación no se establece, salvo que tenga lugar durante el año siguiente a la fecha de la separación.

68. En este sentido el plazo mínimo admitido por sunnies y ši'ies es de seis meses en base a los preceptos coránicos-Cor. XLVI, 15 y Cor. XXXI, 14-, que permiten por deducción establecer ese término mínimo. De manera que si el hijo nace en perfectas condiciones después de seis meses de embarazo el hijo se atribuye al marido y si nace antes de ese término respecto al momento de celebración del contrato matrimonial será considerado ilegítimo. El padre podrá reconocer el hijo nacido antes del término de seis meses, con la condición de que no haga mención a la concepción ilegítima, y tendrá el hijo reservados los mismos derechos que el legítimo. Ahora bien en caso de disolución del matrimonio y para el supuesto que nazca un hijo antes de tal circunstancia, el periodo máximo -no fijado en el Corán- sino en base a tradiciones y declaraciones de la esposa del Profeta, 'Aiša, se barajan dos años, e incluso según Ibn Qudāma, (Mugini, VII, 477), hasta tres y seis años. Sobre el término máximo del embarazo, LINANT DE BELLEFONDS, Y.: Traité de Droit musulmán comparé, Paris-La Haya, Mouton\&Co, 1973, pp. 36-37.

69. A partir de lo dispuesto en el Libro III, «De la filiación y sus efectos». Capítulo III La guarda del niño (hadāna) se justifican los cambios de la reforma de 1992. Reformado por "Ley promulgada por el dahir n 1-04-22 de 3 de febrero de 2004" y publicada en Bulletin officiel, 2005-10-06, $\mathrm{n}^{\circ}$ 5358, pp. 667-701.

70. Véanse los art. 143 y 156 de la Mudawana, op. cit.. El tema ha sido abordado con anterioridad a las recientes reformas, como así queda justificado en la exposición de motivos de la misma; en este sentido véase el punto de vista de la doctrina, y así por ejemplo CHAFI, M.: "L'enfant né hors mariage au Maroc», Revue marocaine de Droit et d'Économie du Développement, 19 (1989), pp. 133-152.

71. Cap. 14. De la filiación (al-nasab). Art. 148. 
El Estatuto Personal Sirio, introdujo en la redacción de 1953 una serie de reformas que afectaban, entre otros, al tema controvertido de la teoría del niño dormido ${ }^{72}$, fijando en un año el plazo máximo de embarazo (art. 128), y determinando las circunstancias en las que la tutela del menor es una obligación para los cónyuges en todo momento, y de forma más cuidadosa en caso de separación (art. 146.2). En 1975 se acometen una serie de modificaciones, consideradas también insuficientes respecto a mayores logros en el campo del derecho de la mujer y de la familia, y concretamente referidas a los hijos habidos fruto de la relación conyugal. Modificaciones que, en la misma línea, se han efectuado en Egipto-mediante textos legales redactados al efecto- o en Sudán -en este caso por medio de circulares judiciales, caso de la Circular núm. 41 de 1935 por la que se regula el plazo máximo del embarazo-.

El código kuwaití determinó el plazo de un año -trescientos sesenta y cinco días- como máximo de embarazo, y el período mínimo es de seis meses lunares. Y como corolario de esta cuestión tan controvertida se ha reglamentado el modo de ejercer la acción de impugnación de la paternidad matrimonial, estando legitimados para ello la madre, el hijo o el Ministerio Fiscal en previsión de la protección de los derechos del menor.

Todas estas reformas se han prolongado durante las últimas décadas del siglo pasado, debiendo señalar entre las últimas reformas la acontecida en Yemen del Norte, país fiel a la tradición en el que en 1978 se promulgó la ley sobre la familia, Qanun al-usrah, conforme a los principios de la escuela zaid $\imath^{3}$, seguida por la mayor parte de la población yemeni ${ }^{74}$ y objeto de reforma recientemente ${ }^{75}$. El anterior texto, de corte más conservador, fijaba la duración máxima del embarazo en tres o cuatro años, siendo el médico la persona competente para determinar la filiación del niño por razón del tiempo de gestación. Tal normativa que fue sustituida en la reciente reforma de 1992 al fijar el período mínimo del embarazo en seis meses lunares y el máximo en trescientos sesenta y cinco días (art. 166).

72. Art. Lib. III, Del nacimiento y sus efectos. Cap. $2^{\circ}$ De la custodia. Art. 139.2.

73. Movimiento šiís moderado surgido a mediados del siglo XI, y que en materia de derecho matrimonial no acepta el de carácter temporal (mut'a); MAílLo SALGADO, F.: Diccionario de derecho islámico, op. cit., p. 473-474.

74. Se trata de una forma moderada del shi'ismo; cuyo fundador fue Zaid ibn 'Ali, o quinto imam del Islam. Sobre su obra véase AL-WASITI, Halid: Magmu al-figh, Milán, Griffini, Corpus Iuris di Zaid ibn 'Ali, 1919; Bousouet, G.M. y Beroues, J. (trads.): Recueil de la Loi Musulmane de Zaid ben 'Ali, Argel, La maison des livres, 1941.

75. En este sentido destaca el estatuto personal para Yemen del sur del año 1974 que fue sustituido por el Código otorgado en 1992 con validez en todo el Yemen. 


\section{LA ADOPCIÓN (TABANNI ${ }^{6}$ ) Y EL ACOGIMIENTO (KAFALA ${ }^{77}$ ) EN EL DERECHO ISLÁMICO: LA ADAPTACIÓN A LOS SISTEMAS JURÍDICOS ACTUALES ${ }^{78}$}

\subsection{Aspectos generales según el Derecho islámico tradicional}

El lector interesado en estos temas debe partir del hecho de que en el Derecho musulmán la filiación es una materia prácticamente inmutable respecto a la legislación que la regula de hecho, las pocas reformas acaecidas se refieren a la presunción de paternidad. Por otro lado la adopción, tabannī, esta prohibida por el Derecho islámico ${ }^{79}$, si bien durante la etapa preislámica se ejercía bajo los mismos presupuestos que se conocen en la actualidad ${ }^{80}$.

A tenor de los planteamientos generales expuestos en la mayoría de los Estatutos y Códigos de los diversos países mencionados se explica la ausencia de esta institución. Una vez más las exigencias del orden internacional conllevan a la búsqueda de soluciones en el plano jurídico que permitan dar carta de naturaleza a situaciones controvertidas.

La legislación contemporánea, a través de los Códigos y Estatutos personales, apenas aborda la cuestión, a diferencia de lo que sucede respecto al reconocimiento de la paternidad, materia objeto de profusa reglamentación. Las modificaciones introducidas en materia de adopción se evidencian en la legislación tunecina -por influencia de la presencia francesa y de su legislación en este país-, que se introdujo mediante un anexo a la ley (n. 58-27 de 4 de marzo de 1958) y que solo se prevé respecto a los menores (art. 12). En este sentido, y ante las situaciones de indefensión que se están dando en España en los últimos años, el Ministerio de Trabajo y Asuntos sociales, a través de la Secretaría de Asuntos sociales y la Dirección General de Acción Social del Menor y la Familia aborda la tutela dativa, respecto a menores marroquíes en territorio español, y ha generado un procedimiento que a continuación se expone y que responde a la modalidad kafăla ${ }^{81}$. En realidad la kafâla es la acción de hacerse cargo de un niño abandonado y atender a las necesidades de quienes por distintas circunstancias, tienen necesidad de ser atendidos por una familia sustituta, una acción de carácter humanitaria que como tal supone el «acogimiento en una familia de un menor indigente, con el fin de educarlo y de ocuparse de él material y

76. NAQVI, A.R.: "Adoption in Muslim Law», Islamic Studies, 19 (1980), pp. 283-302.

77. s.v. «kafala» en $E I^{2}$, op. cit., vol. IV, Leiden, Brill, 1990, pp. 404-405. Y en el marco del derecho islámico clásico SCHACHT, J.: Islamic law, Oxford, Oxford University Press, 1964, pp. 158-159.

78. UtRera GutiéRReZ, J.L.: "Protección de menores: Acogimiento, adopción y tutela» en Tratado de Derecho de Familia, cap. V, op. cit., pp. 291-364; CILARDO, A.: Il Diritto islamico e il sistema giuridico italiano, op. cit., pp. 270-271. GOVERNMENT OF TUNISIA y MAHMOOD, T.: «Tunisia: Law of Guardianship and Adoption (Law núm. 58-67 of 4 march, 1958 as amended by Law núm. 59-69 of 19 June, 1959)", Islamic and Comparative Law Quaterly, 1 (1981), pp. 226-231. El lector interesado encontrará abundantes referencias al respecto en http://www.afada.org/docus/africa000fichatec.htm.

79. Cor. XXXIII, 4-5.

80. LinANT DE BELLEFOndS, Y. : Traité, op. cit., pp. 22-25.

81. s.v. «kafăla» en $E I^{2}$, vol. IV, Leiden, Brill, 1990, pp. 404-405. 
moralmente como si fuera su propio hijo, sin que ello produzca efectos sobre su filiación.

La característica principal de la institución de la kafāla es la de no producir efectos de filiación entre el menor y la persona que lo toma a cargo, por lo que aquél, nunca rompe sus vínculos con su familia de origen ${ }^{82}$. El hecho de que la kafâla no produzca ningún efecto jurídico sobre la filiación es la razón por la cual es necesario que para que una familia española se pueda hacer cargo de un niño de origen marroquí debe, una vez instituida la kafāla de un niño declarado abandonado, solicitar del juez de menores, tutor por ley de todos los niños abandonados, la tutela dativa del mismo. En este caso la tutela confiere el ejercicio de la patria potestad y, como consecuencia, la representación legal del niño tutelado.

\subsection{Sobre el procedimiento administrativo en materia de acogimiento: la adaptación del ordenamiento islámico a las exigencias internacionales}

La proliferación de matrimonios mixtos y los cambios de residencia por razones de trabajo o causas análogas obligaron también a modificar el texto anterior, concretamente en lo dispuesto en los artículos 15, 16 et 17 de la Ordenanza $\mathrm{n}^{\circ} 75-58$ de 26 de septiembre de 1975; en este sentido se reglamenta que las condiciones de fondo en materia de tutela testamentaria, curatela y otras instituciones de protección de menores, de incapaces y de ausentes, serán determinadas por la ley nacional de la persona a proteger. En todo caso, cuando de medidas de urgencia se trate sobre menores, incapaces y ausentes encontrados en Argelia, se adoptaran estas medidas, así como si sus bienes se encuentran en territorio argelino.

La protección del menor recibe especial atención por el Derecho islámico, que regula desde tiempo inmemorial instituciones acordes con el principio de protección y defensa de los intereses del menor. En este sentido el papel relevante que desde antaño desempeña el padre en la acción tutelar es un hecho innegable, y sujeto a la adaptación de las exigencias del derecho actual. Desde tiempo inmemorial el padre ejercía un papel fundamental en la celebración del matrimonio de la hija; esta intervención quedaba justificada por el hecho de que el padre es quien ejerce la patria potestad sobre los hijos hasta que éstos llegan a la pubertad, y sobre las hijas hasta el momento de la consumación del matri-

82. Una situación que dista mucho del supuesto contemplado en la legislación española de filiación por naturaleza no matrimonial; regulado por el art. 120 del C.C. contempla cuatro supuestos: reconocimiento formal, resolución recaída en el expediente tramitado con arreglo a la legislación del Registro Civil y por sentencia firme; estos supuestos se refieren al padre. Para el caso de la madre la filiación en restos casos se atribuirá cuando se haga constar en la inscripción del nacimiento. En todos estos supuestos los efectos vendrán determinados por el cumplimeitno de los requisitos establecidos en el art. 121 y ss del C.C.. Calvé Corbalán, C.: Tratado de derecho de familia, op. cit., cap. IV, «Filiación», p. 241. 
monio ${ }^{83}$. De ahí que sea el padre a quien competa en primer lugar el ejercicio de la tutela, wilāya $a^{84}$, hasta el momento en que por razón del matrimonio la hija es entregada a su futuro esposo. Esta autoridad que es reconocida al padre tanto en la esfera temporal como espiritual, e incluso en ambas y que supone también la potestad de representar a una persona que por razones diversas, ve reducida su capacidad para actuar.

El poder de representación sobre el tutelado permite distinguir dos categorías: la custodia de menores (hadāna al-ṣagìr) y la custodia de una persona (wil.ayat al-nafs) que superada la edad de la infancia se encuentra en situación de incapacidad por razones diversas ${ }^{85}$. Incluso es el padre quien, en su condición de walì de la hija virgen y púber, debe administrar aquéllos bienes de la dote que le han sido transmitidos por razón del casamiento ${ }^{86}$. Situación que, a tenor de los tiempos modernos, es considerada anacrónica y alejada de los presupuestos de la normativa vigente en la mayoría de los países islámicos, experimentando un proceso de revisión y adaptación a las circunstancias de la sociedad actual.

La protección del menor por entidades públicas, en el marco jurídico de la adopción internacional, ha favorecido el reconocimiento de instituciones particulares que permitan ajustar la realidad vivida por los menores abandonados a las necesidades planteadas ante los organismos competentes en esta materia ${ }^{87}$. La figura del tutor del menor y los organismos tutelares, el defensor o juez de adopciones adquieren razón de ser en una sociedad que se enfrenta a problemas constantes de inmigración de menores y abandono de los mismos en países ajenos a su cultura y a la legislación que le es reconocida en sus países de origen.

Los sistemas jurídicos inspirados en el Corán, como ocurre con el Código del Estatuto Personal marroquí, Mudawana, no contemplan la institución de la adopción. Argelia es otro de los países del ámbito magrebí que se ha ocupado de esta institución, concretamente a través del art. 13 de su reciente reforma del Estatuto personal ${ }^{88}$. Reconoce la validez de acogida legal, kafäla, y se somete

83. Véase al respecto la voz «saghîr» en $E I^{2}$, vol. III, Leiden, Brill, 1995, pp. 821-825. En este mismo sentido se pronuncian BELLEFONDS, Y.L.: Traité..., op. cit., p. 179 y SANTILLANA, D.: Istitutioni di Diritto musulmano, con riguardo anche al Sistema Sciafiita, op. cit., t. I, p. 295 y t.II, pp. 197-199.

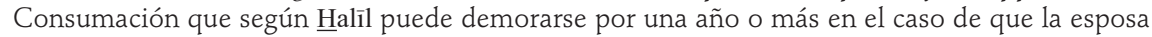
sea «demasiado joven", legitimando así la celebración de esponsales cuando la mujer es de corta edad (HALİl IBN IsḤ̂AQ: "Il Muhtașar» Sommario del Diritto Malechita, op. cit., vol. II, p. 41).

84. Sobre el término véase voz "wil...ya» en $E I^{2}$, vol. XI, Leiden, Brill, 2002, pp. 208-209.

85. S.v. «wālaya» en $E I^{2}$, vol. XI, Leiden, Brill, 2002, p. 208.

86. Chalmeta Gendrón, P., y Corriente, F.: Formulario notarial de Ibn Al-'Attêr, Madrid, Academia Matritense del Notariado, 1983, pp. 339-340; y en el mismo sentido véase CHALMETA GENDRON, P.: «Acerca del 'amal en Al-Andalus: algunos casos concretos», A.H.D.E., 57 (1987), p. 358. Sobre la potestad del representante legal de la mujer véase "walī» en $E I^{2}$, vol. XI, Leiden, Brill, 2002, pp. 109-125.

87. Enfance et Familles d'Adoption (EFA): para más información: http://www.adoptionefa.org/accueil.php y http://www.efa78.org.

88. Art. 13 ter. - La validité du recueil légal (Kafala) est soumis simultanément à la loi nationale du titulaire du droit de recueil (Kafil) et à celle de l'enfant recueilli (Makfoul) au moment de son établissement. Les effets du recueil légal (Kafala) sont soumis à la loi nationale du titulaire du droit de recueil (Kafil). L'adoption est soumise aux mêmes dispositions». Remítase el lector a 
simultáneamente a la ley nacional del titular del derecho de acogida, $k a \overline{f i l l}$, y a la del niño sobre la que se ejerce, makful, en el momento de su establecimiento. Y apostilla el mismo texto que la adopción (tabannī) se regirá por las mismas disposiciones.

De manera que la kafâla consiste en el hecho de acoger (recoger) legalmente, a un menor suministrándole los medios necesarios para su mantenimiento, educación, y protección. De la misma manera que lo haría un padre con su hijo. Está establecida por un acto auténtico y sincero.

El acogimiento legal es acordado ante un juez «kafăla judicial», o ante notario «kafăla notarial» y requiere el consentimiento del niño si éste tuviese padre o madre. El titular del derecho de acogimiento legal (käfil) debe ser musulmán, estar en su sano juicio, ser íntegro, poder mantener al niño acogido (makful) y capaz de protegerlo. El niño acogido puede ser de filiación conocida o desconocida, ateniéndose en todo caso la acogida a los acuerdos bilaterales entre España y los distintos países, conforme a lo dispuesto en su ordenamiento jurídico y la normativa internacional ${ }^{89}$.

En Marruecos, el sistema judicial autoriza el tanzil, o gratificación testamentaria que permite al niño (makful), percibir una cierta parte de la herencia. En Argelia (tras el Decreto n 92-24 del 13 de enero de 1992 que completa la decreto $\mathrm{n}^{\circ}$ 71-157 del 3 de junio de 1971 relativo al cambio de nombre), el makful, del menor recogido, si es de padre desconocido, puede cambiar de nombre haciéndolo coincidir con el nombre patronímico. Incluso en ocasiones la citada institución, kafāla judicial, ha sido interpretada como adopción, especialmente cuando no existía una filiación establecida o los padres biológicos habían consentido con esta modalidad ${ }^{90}$.

El procedimiento para la constitución de una kafāla se atiene a lo dispuesto en la legislación específica sobre esta institución ${ }^{91}$. Si el solicitante de la kafâla del menor abandonado es un extranjero deberá, en primer lugar, convertirse al

«Loi n 05-10 du 13 Joumada El Oula 1426 correspondant au 20 juin 2005 modifiant et complétant l'ordonnance $n^{\circ} 75-58$ du 26 septembre 1975, modifiée et complétée, portent code civil», en Journal Officiel De La Republique Algerienne, $\mathrm{n}^{\circ}$ 44, pp. 14-15.

89. Por razón del objeto y finalidad de este trabajo no ha lugar la exposición detallada de estas normas, ni siquiera en el marco del derecho comparado, por lo que el lector interesado debe remitirse a lo dispuesto en la normativa legal, que puede ser consultada en la página web de la Secretaría General de Asuntos Sociales del Ministerio detrabajo y Asuntos Sociales, Dirección General de Acción Social, del Menor y de la Familia, Subdirección General de Infancia y Familia.

90. Supuesto que se hizo patente antes de la Circular del 16 de febrero de 1999 relativa a la adopción internacional. En este sentido, el Derecho marroquí establece que el niño tomado a cargo y protegido como legítimo no podrá beneficiarse de una nueva filiación. Ley francesa ${ }^{\circ}$ 2001-111 de 6 de febrero 2001-relativa a los conflictos legales en la adopción internacional. Y un tratamiento análogo se da en la legislación argelina. La pluralidad de situaciones sobre estos casos ha dado lugar a un movimiento asociacionista de importancia en algunos países europeos, siendo Francia ejemplo al respecto. Fuente: Zaynab Alkaraz http://www.afada.org/docus/africa000fichatec.htm.

91. Ley 165/93, la Circular del Ministerio del Interior de 1983 y el Código del Estatuto Personal (Mudawana). 
Islam, en un acto ante dos adultos (notarios) y dos testigos ${ }^{92}$; este requisito se debe a que la kafála sólo puede constituirse a favor de los musulmanes, siendo preceptiva el Acta de conversión o profesión de la fe islámica, junto con otros documentos debidamente legalizados ${ }^{93}$.

Una vez completado el expediente se hará llegar al máximo órgano de representación local, wilāya ${ }^{94}$, o a la Prefectura; desde ese momento una asistente social y un qaíd acometerán cuantas acciones sean precisar para conocer a la familia aspirante al acogimiento. El matrimonio debe mantener un encuentro con las citadas personas y tras la conclusión de las encuestas se remitirán, con toda la documentación, al Ministerio del Interior, que es el organismo competente para aprobar o denegar el expediente. Si el Ministerio del Interior decide la autorización del expediente, éste se enviará de nuevo a la wilāya o Prefectura, donde se vuelve a convocar a los padres y en un plazo aproximado de 24 horas, el wầli -en su condición de persona de autoridad y gobierno que esta a cargo de alguna otra persona $a^{95}$-autoriza la entrega del menor y la constitución de la kafäla.

Constituida la kafăla deberá solicitarse la tutela dativa que confiere la representación legal sobre el menor. La legislación marroquí establece que la tutela del menor abandonado corresponde al Juez encargado de Menores en el Tribunal de Primera Instancia ${ }^{96}$. No obstante, el art. 152 de la Mudawana permite la constitución de una tutela dativa, al señalar que será tutor dativo de un menor la persona que designe el juez. Por ello, junto a la solicitud de autorización de salida del territorio nacional, debe solicitarse al Juez de menores que nombre tutor del menor al kafil. Tras la decisión del juez de menores, el matrimonio deberá acudir al Tribunal de Primera Instancia para que confirme la autorización del juez de menores.

Una vez obtenida la confirmación del Tribunal de Primera Instancia, el matrimonio debe volver a la wilàya para que ésta proceda a expedir un pasaporte marroquí al menor. Tras obtenerlo deben dirigirse al Consulado español correspondiente, con todo el expediente traducido, para solicitar el correspondiente visado de entrada en España.

Así pues, la tramitación en España de un expediente de tutela dativa de un menor de origen marroquí debe tener en cuenta las características especiales de

92. Requisitos exigidos en la Circular de 1983 y en el art. 7 de la Ley 165/93.

93. Certificado de nacimiento, el certificado de matrimonio, con un mínimo de dos años de matrimonio; certificado de solvencia económica.; certificado de trabajo; certificado médico; encuesta psico-social; certificado de antecedentes penales; certificado de residencia y certificado de idoneidad. Todos estos documentos traducidos al francés o al árabe. Además, una solicitud de un certificado de alojamiento, en el que se establece que dicho matrimonio tiene domicilio en Marruecos, ya que la Circular de 1983 exige este requisito a los ciudadanos extranjeros que quieran constituir una kafăla.

94. S.v. «wilaya» en $E I^{2}$, op. cit., vol. XI, Leiden, Brill, 2002, pp. 208-209.

95. Institución que tiene su orgien en el texto coránico, XIII, 12; sobre sus funciones y competencias véase $E I^{2}$, vol. XI, Leiden, Brill, 2002, pp. 109-116.

96. Art.6 de la Ley $165 / 93$ y art. 147 y ss. de la Mudawana. 
esta tramitación, con el fin de asegurar a los interesados que el trámite que inician en Marruecos está configurado para el supuesto de niños abandonados ${ }^{97}$. Este es el único supuesto previsible, y exige el cumplimiento de una serie de requisitos ante el Consulado español correspondiente ${ }^{98}$.

97. Recogidos en una serie de Centros como el Hospital Asan de Nador, el Lalla Meriem de Rabat, el Centro Hospitalario al- Ghassani de Fez y la Ligue Marrocaine pour la Protection de I'Enfance, Bureau de Marrakech en Marraquech.

98. El envío del certificado de idoneidad e informes psico-sociales, junto con un escrito de constatación del Centro en el que han iniciado el trámite, en el cual conste la identidad de los adoptantes (nombre y apellidos); los informes psico-sociales y el certificado de idoneidad deben hacer referencia siempre a una tutela dativa y no a la adopción -la razón: por ser la adopción una figura no reconocida en la legislación islámica y, como consecuencia, considerar la tutela dativa la única figura que permite, por sus garantías jurídicas, la entrada con visado del niño en España. Los interesados tramitan directamente su documentación personal - de manera que los informes psico-sociales y certificado de idoneidad remitidos por las Comunidades Autónomas se envían, desde este Ministerio, por valija diplomática, al Consulado español correspondiente de Marruecos para su remisión al Centro correspondiente. La documentación, junto a la autorización del juez encargado de asuntos notariales y de menores para que el menor viaje fuera del territorio nacional y conviva o resida habitualmente con la familia que le acoge en el extranjero, deberá ser remitida ante el Consulado General de España en Rabat, para el caso de Marruecos. 